 \\ UF | FLORIDA \\ UF
}

\section{Horizon 474 - A new winter oat cultivar for both grain and forage ${ }^{1}$}

Ann Blount, Ronald Barnett, Jerry Johnson, Cheryl Mackowiak, and Yoana Newman²

Horizon 474 is a new winter oat cultivar that was co-developed by the University of Florida (UF) and the Georgia Agricultural Experiment Station (UGA) and was released in 2002. Horizon 474 has considerable potential for both grain and forage production in the southeastern U.S. The new oat was selected from material donated by Northrup-King Seed Company to the USDA-ARS. Horizon 474 was derived from a bulk population, which originated from the cross: Coker 84-15/TX84Ab2131. Coker 84-15 is an unreleased advanced line that was tested in the 1985 Uniform Winter Oat Nursery. The TX84Ab2131 is a StateplaceTexas breeding line where the crown rust resistance genes from TAM O-301, TAM O-312, Coker 227, and Coker 234 were combined with the stem rust resistance gene from Alpha (CI9221). This is the same source of stem rust resistance present in Steele, TAMO 386, and TAMO 397.

As with most eastern oat varieties, Horizon 474 is susceptible to Barley Yellow Dwarf Virus (BYDV) infection. Delaying planting until cooler weather prevails tends to alleviate the spread of the virus since it is aphid vectored. When planted early fall for forage, Horizon 474 is very disease resistant although BYDV infection may result in some stunting and leaf discoloration.

\section{$\underline{\text { Grain Production }}$}

Horizon 474 is a white seeded oat. It has excellent test weight, is early maturing, and has good crown rust resistance. In comparison to Florida 501, a very popular older cultivar, Horizon 474 has higher grain yield, higher test weight, stronger straw, better crown rust resistance, and appears to be more winter hardy. Three-year average oat grain yield for Horizon 474 was $120 \mathrm{bu} / \mathrm{A}$ in Georgia. Horizon 474 has similar maturity to Florida 501 and it is $7-10$ days earlier maturing than Horizon 314, a popular variety released several years ago.

\section{$\underline{\text { Forage Production }}$}

Horizon 474 has been a reliable forage producer and is recommended for grazing and hay production. This oat also fits well in dairy silage operations where high quality cool-season forages are utilized for greenchop or silage. Three-year seasonal forage yield

1. This document is SS AGR 281 one of a series of the Agronomy Department, Florida Cooperative Extension Service, Institute of Food and Agricultural Sciences, University of Florida. Original publication date October 2007. Visit the EDIS Web Site at http://edis.ifas.ufl.edu.

2. Ann Blount, associate professor, Agronomy Department, North Florida Research and Education Center--Marianna, FL; Ronald Barnett, professor, Agronomy Department, North Florida Research and Eduction Center--Quincy, FL; J.W. Johnson, University of Georgia; Cheryl Mackowiak, assistant professor, North Florida REC - Quincy, FL; Yoana Newman, assistant professor, Agronomy Department; Florida Cooperative Extension Service, Institute of Food and Agricultural Sciences, University of Florida, Gainesville, FL 32611.

The Institute of Food and Agricultural Sciences (IFAS) is an Equal Opportunity Institution authorized to provide research, educational information and other services only to individuals and institutions that function with non-discrimination with respect to race, creed, color, religion, age, disability, sex, sexual orientation, marital status, national origin, political opinions or affiliations. U.S. Department of Agriculture, Cooperative Extension Service, University of Florida, IFAS, Florida A. \& M. University Cooperative Extension Program, and Boards of County Commissioners Cooperating. Larry Arrington, Dean 
for Horizon 474 was $7645 \mathrm{lb} / \mathrm{A}$ in Georgia and two-year yield averaged $4941 \mathrm{lb} / \mathrm{A}$ in north Florida under dryland conditions. Horizon 474 was released exclusively to Plantation Seeds, Inc., Newton, GA.

Horizon 474 oat is considered to be an excellent choice for grain, hay, grazing or ensiling in the southeastern U.S. 